\title{
AMP-Student: Challenges for Scientific Publishing
}

\section{AMP-Student: Desafios para a Publicação Científica}

\author{
Pedro Câmara PESTANA $\triangle^{1,2}$, Ana Rita RAMALHO ${ }^{3,4}$, Bernardo Marques da SILVA ${ }^{5,6}$, Joana REVÉS ${ }^{5,7}$, \\ Mariana FERNANDES ${ }^{5,6}$, Sandra MAURÍCIO 2,5 \\ Acta Med Port 2016 Mar;29(3):159-160 - http://dx.doi.org/10.20344/amp.7504
}

Keywords: Periodicals as Topic; Publishing; Students, Medical; Writing.

Palavras-chave: Estudantes de Medicina; Portugal; Publicação; Redação; Revistas.

Nowadays, medical students start to use scientific journals at an early phase, with an increasing tendency of its use as they advance in their pre and post-graduated training. Scientific publication acts, therefore, as invisible curricula, providing the students with an intuitive way to understand core curricular knowledge.

Unfortunately, there have been some barriers to publication by medical students ${ }^{1}$ and, despite their rapid increase in number worldwide, ${ }^{2}$ student journals face major challenges. The quality of these journals remains a source of debate ${ }^{2}$ due to concerns regarding the credibility of the students' peer-reviewed process, the hypothetical lack of research projects developed by students and the widespread preconception that student journals are repositories of lowquality science that would not be accepted in other journals. Nevertheless, student journals play a remarkable role as an engine to encourage students to engage in research projects and provide an opportunity for first contact with the submission and peer-reviewed process, which would not be possible in other highly competitive journals. ${ }^{2,3}$

We are happy to announce that the universe of student journals now includes AMP-Student (AMP-S) - a recent section of Acta Médica Portuguesa, which is the scientific journal published by Ordem dos Médicos (Portuguese Medical Association). It is our belief that, as far as quality standards go, student journals may be critical to the improvement of students' research skills and training for future authors, reviewers and editors.

The aim of AMP-S is to promote science communication between students and junior doctors by publishing their original research and review articles on several domains of medical knowledge, assured that this is done under a strict quality policy guaranteed by a rigorous peer-review process shared with the 'mother' journal. To achieve that purpose, we are implementing a new nationwide editorial board model, composed by one Editor-in-chief, five Associate Editors and eight Local Representatives (one in each Portuguese medical school). We intend to launch a new and more dynamic stage for AMP-S, with a strategy focused on establishing a close relationship with Portuguese medical schools, not only by attracting good scientific content for publication, but also supporting medical students and junior doctors in their education. In addition, and for the first time, the annual Acta Médica Portuguesa Symposium will have a day exclusively dedicated to student and junior doctor subjects. Finally, we expect to promote AMP-S internationally and to bring worldwide students' science together in the AMP-S platform.

Despite medical curricula's great focus on clinical skills and theoretical contents, becoming a doctor is an endless process which involves the acquisition of different competences on numerous fields. Thus, students' predisposition to seek knowledge and their participation in different projects will be crucial in the definition of the sort of doctor they become. We believe that, by giving medical students a platform to learn how to communicate science and with useful contents, opinion spaces and forums, AMP-S is facilitating the introduction to scientific thinking.

We would like to invite you to join us. We need your enthusiasm and your ideas. Whether for scientific articles or online posts, feel free to contribute - feel free to help us build AMP-S.

\section{ACKNOWLEDGEMENTS}

The authors would like to thank Liliana Nanji for the critical review of the manuscript.

\footnotetext{
1. Editor-in-chief. AMP-Student. Lisboa. Portugal.

2. Junior doctor. Hospital Professor Fernando da Fonseca. Amadora. Portugal.

3. Associate Editor. AMP-Student. Porto. Portugal.

4. Student. Faculdade de Medicina. Universidade do Porto. Porto. Portugal

5. Associate Editor. AMP-Student. Lisboa. Portugal.

6. Student. Faculdade de Medicina. Universidade de Lisboa. Lisboa. Portugal.

7. Student. NOVA Medical School. Faculdade de Ciências Médicas. Universidade NOVA de Lisboa. Lisboa. Portugal.

$\square$ Autor correspondente: Pedro Câmara Pestana. actamedicaportuguesastudent@gmail.com

Recebido: 10 de fevereiro de 2016 - Aceite: 10 de fevereiro de 2016 | Copyright @ Ordem dos Médicos 2016
} 


\section{REFERENCES}

1. Maghrouni M, Mahian O, Wongwises S. Some review journals do not allow students to author reviews: is this ethical? Sci Eng Ethics. 2015. [Epub ahead of print].

2. Aboshady OA, Gouda MA. Pros and cons of student journals. Perspect
Med Educ. 2016;5:63-4.

3. Funston $\mathrm{G}$. The promotion of academic medicine through student-led initiatives. Int J Med Educ. 2015;6:155-7. 